\title{
Exploitation of Agro-Industrial Residues for the Formulation of a New Active and Cost Effective Biofungicide to Control the Root Rot of Vegetable Crops
}

\author{
Mohamed Hashem 1,2,*(D), Yasser S. Mostafa ${ }^{1}$, Saad Alamri ${ }^{1}$, Ahmed M. Abbas ${ }^{1,3}$ and Ebrahem M. Eid ${ }^{1,4}(\mathbb{D}$ \\ 1 Biological Science Department, Faculty of Science, King Khalid University, P.O. Box 10255, \\ Abha 61321, Saudi Arabia; ysolhasa1969@hotmail.com (Y.S.M.); saralomari@kku.edu.sa (S.A.); \\ ahhassan@kku.edu.sa (A.M.A.); ebrahem.eid@sci.kfs.edu.eg (E.M.E.) \\ 2 Botany and Microbiology Department, Faculty of Science, Assiut University, Assiut 71516, Egypt \\ 3 Department of Botany and Microbiology, Faculty of Science, South Valley University, \\ Qena 83523, Egypt \\ 4 Botany Department, Faculty of Science, Kafrelsheikh University, Kafr El-Sheikh 33516, Egypt \\ * Correspondence: mhashem@kku.edu.sa; Tel.: +966-172-417-625
}

\section{check for} updates

Citation: Hashem, M.; Mostafa, Y.S.; Alamri, S.; Abbas, A.M.; Eid, E.M. Exploitation of Agro-Industrial Residues for the Formulation of a New Active and Cost Effective Biofungicide to Control the Root Rot of Vegetable Crops. Sustainability 2021, 13, 9254. https://doi.org/ $10.3390 /$ su13169254

Academic Editors: Lucian-Ionel Cioca and Dilip Nandwani

Received: 2 July 2021

Accepted: 9 August 2021

Published: 18 August 2021

Publisher's Note: MDPI stays neutral with regard to jurisdictional claims in published maps and institutional affiliations.

Copyright: (c) 2021 by the authors. Licensee MDPI, Basel, Switzerland. This article is an open access article distributed under the terms and conditions of the Creative Commons Attribution (CC BY) license (https:// creativecommons.org/licenses/by/ $4.0 /)$.

\begin{abstract}
This study aimed to produce an economic and stable biofungicide based on a new effective antagonistic strain (Trichoderma harzianum JF419706) via the exploitation of agro-industrial lignocellulosic residues as carriers for fungal growth to control the root rot diseases of vegetable crops. Trichoderma harzianum JF419706 showed a good resistance to a chemical fungicide with two-fold of the recommended dose. It was able to propagate on corn stovers amended with $20 \%$ of date molasses, as a very cheap substrate, up to $2.90 \times 10^{16} \mathrm{CFU} / \mathrm{g}$ after 30 days. Formulation of the bioagent on the substrate as a fine powder (FTB) increased the shelf-life up to 8 month with good viability $\left(9.37 \times 10^{11} \mathrm{CFU} / \mathrm{g}\right)$. The bioagent propagated itself in the rhizospheric soil about two-fold of the initial inoculum. Application of the FTB, as a seed treatment, suppressed the root rot disease severity percentage of cucumber, lettuce, and tomato plants to $70.0 \%, 61.5 \%$, and $53.8 \%$, respectively, from the control. The crop yield increased by 50\%, 35\%, and 30\% in the same order of the three crops. FTB promoted the growth and physiological processes of the plants significantly compared with the control. Our study recommends the application of the FTB as a cost-effective biofungicide and biofertilizer in crop management, singly or as a part of integrated pest management, to ensure the sustainability of green farming and reduce the chemical input in cultural practices.
\end{abstract}

Keywords: biofungicide; agro-wastes; biofertilizer; cucumber; lettuce; tomato; Trichoderma harzianum; root rot; sustainability

\section{Introduction}

Soil-borne pathogens attack a wide range of horticultural and vegetable crops, causing a great reduction in the yield, and have become a global challenge facing sustainable production under greenhouse and field conditions, especially in organic farming [1-4]. Chemical fungicides are still the main strategy for the control of soil-borne diseases; however, with growing public awareness and organic farming practices there is a need to reduce the chemical inputs in agricultural systems [5-7]. From the ecological point of view, sustainable development is given a great importance as an environmental policy all over the world. It is very difficult to achieve sustainable development unless environmental ethical approaches can be harmonized. Therefore, it is very important to apply safe and non-hazardous materials into the soil and avoid the soil contamination with toxic substances and heavy metals or human pathogenic microorganisms that could contaminate soil and water resources [8-10].

On the other hand, many pathogens can build up a resistance against several pesticides that could become less effective in managing the diseases [11,12]. Integrated pest 
management (IPM) was applied as an alternative strategy for soil-borne diseases' control to reduce the input of chemical pesticides to the environment [13,14]. A biological control that uses antagonistic microorganisms with the ability to suppress target pathogens was used as an important ingredient of the IPM strategy $[15,16]$. For a biological control strategy, the main challenge is the production of a commercial product with a long shelf-life that could have a competitive efficacy with the chemical fungicides [17]. Effective formulation is the key factor in the development of any biocontrol agent [18,19]. Many laboratories and companies have developed specific microorganisms to use them as an effective ingredient of preparation in the biological control of many plant diseases [20-22]. Despite the initial success and extensive research efforts, progress in achieving large-scale usage of commercial biopesticides is going slowly $[7,23]$. When trials were conducted on the field scale, many candidates fail to confirm their activity and consequently lack the reliability [2,22,24].

Many microorganisms were used to develop commercial biocontrol products due to their efficacy in suppressing the pathogens under field conditions [25-27]. Beauveria, Hirsutella, Lecanicillium, Metarhizium, Paecilomyces, Trichoderma, and Verticillium are among the common fungal genera that were used to produce commercial biopesticides [28,29]. Trichoderma strains were reported as a successful biofungicide for management of a dampingoff disease caused by Rhizoctonia solani [30] and Fusarium [31]. Khan et al. [32] showed that most formulated and unformulated Beauveria bassiana biopesticides achieved the target pest control. A biofungicide comprises several main components, such as effective microbes, carriers, bulking additives, contaminant suppressants, buffering systems, and coating compounds $[33,34]$. The availability of cost-effective production and stabilization of a biocontrol agent is a critical factor that must be considered during the development of a commercial biopesticide [34-36]. The high cost of production is an important reason for the limited commercialization of the biofungicides; therefore, more research is needed to lower the cost production of biofungicide formulation and increase the effectiveness on the field-scale [2,34,35,37].

In our previous works, the new strain Trichoderma harzianum JF419706 showed promising biological control activity against many soil-borne pathogens in both in vitro and in vivo experiments [4,38]. The mode of action of this strain was approved as the production of cellwall degrading enzymes, antibiosis, mycoparasitism, the promotion of plant growth, and the induction of plant defense systems $[39,40]$. Formulation of Trichoderma harzianum has been proven to be effective in suppressing diseases in different plants and under different conditions [41,42], in addition to its effective formulation as a pesticide for many pests [43]. As a success story, the bioformulation of T. harzianum strain ITEM 3636, was reported as an effective biofungicide against peanut smut caused by Thecaphora frezii [44]. However, the successful application of this organism in the field still needs to be confirmed. An appropriate formulation on a suitable carrier that enhances good mass production of the organism in a large-scale application is an important target of the current and future works. We assume that obtaining such an appropriate formulation will enable us to develop a new biofungicide that could fulfill the standard conditions for any successful biopesticide [17].

This study aimed to produce an economic and stable biofungicide based on a new effective antagonistic strain (T. harzianum JF419706) using a very cheap carrier. The formulated biofungicide has a long shelf-life and the ability to control root rot diseases effectively under field conditions.

\section{Materials and Methods}

\subsection{Bioagent Fungus}

Trichoderma harzianum JF419706 was obtained from the rhizospheric soil of healthy lettuce plant, and it was identified by the amplification of the ITS gene using universal primers [45] and assigned the GenBank accession number JF419706 in our previous work [38]. It was selected as a bioagent ingredient because of its high antagonistic capability against several soil-borne pathogens in vitro and in vivo during several successive experiments, and its protective effect for many vegetables $[4,38]$. 


\subsection{Inexpensive Agro-Industrial Residues as Carriers for Mass Production}

Ten inexpensive substrates (sawdust, wheat bran, rice, popcorn, white corn, red corn, wheat straw, corn stalks, corn stover, and barley) were tested for high biomass production of T. harzianum JF419706. These substrates were selected based on their abundance, sustainability, and low pricing. The substrates were presoaked in water $(2-3 \mathrm{~h})$ and supplemented with $20 \%$ date molasses. A total of $200 \mathrm{~g}$ from each substrate were sterilized at $1.1 \mathrm{~kg} / \mathrm{cm}^{2}$ pressure for $15 \mathrm{~min}$ in polypropylene bags (autoclavable bags $20.5 \times 28 \mathrm{~cm}$, Scienceware, USA) and each bag was inoculated with $10 \mathrm{~mL}$ of spore suspension of T. harzianum JF419706 $\left(10^{8} \mathrm{CFU} / \mathrm{mL}\right)$. The bags containing the inoculated substrate were incubated at $27 \pm 1{ }^{\circ} \mathrm{C}$ in the dark for 30 days. From each inoculated substrate, samples $(1 \mathrm{~g} /$ sample) were taken every 10 days for an estimation of the fungal propagation using the dilution plate technique, and the propagation was estimated as colony forming units (CFU/g substrate).

\subsection{Formulation of the Biofungicide (FTB) and Shelf-Life Test}

Trichoderma harzianum JF419706 was grown on corn stovers/molasses carrier (8:2; $w: w)$. The corn stovers were dried and ground into two types of powders: fine (size of particles $<2.0 \mathrm{~mm}$ ) and coarse (size of particles $>2.0 \mathrm{~mm}$ ) and amended with date molasses $(20 \%)$. The carriers were inoculated with the fungal spores $\left(10^{8}\right.$ spore $\left./ \mathrm{mL}\right)$ and incubated at $27 \pm 1{ }^{\circ} \mathrm{C}$ for 30 days. The produced FTB was kept in plastic bags as a solid form of the biofungicide and stored for 8 months at room temperature $\left(10-30^{\circ} \mathrm{C}\right)$. To prepare a liquid form of the FTB, $10 \mathrm{~g}$ of the formulated fine powder was suspended in a 500-mL glass bottle in three different suspensions: (A) invert emulsion, in which $300 \mathrm{~mL}$ of sunflower oil (7.0\%) and dimethyl sulphoxide (1.0\%) were emulsified in $92.0 \%$ of water and mixed with $10 \mathrm{~g}$ of the fine powder of the FTB; (B) molasses emulsion, in which $300 \mathrm{~mL}$ of date molasses $(20 \%)$ was suspended with $10 \mathrm{~g}$ of the FTB; and (C) $300 \mathrm{~mL}$ of sodium alginate (3\%) was suspended with $10 \mathrm{~g}$ of the fine powder of the FTB. The bottles were stored for 8 months at room temperature. To monitor the shelf-life stability during the storage period, $1 \mathrm{~g}$ of the FTB was taken for estimation of the emerged colony of the fungus on the PDA medium by the dilution plate technique, and the viability of the bioagent fungus was expressed as $\mathrm{CFU} / \mathrm{g}$.

\subsection{Resistance of the Bioagent Fungus to the Chemical Fungicide}

To ensure the applicability of the FTB with a high efficiency against the target pathogens even in the presence of chemical fungicides' residue, which could be applied by the farmers, a common fungicide "Rhizolex" was tested for its effect on the growth of the bioagent T. harzianum JF419706 in vitro. Different concentrations of Rhizolex (0.0, 0.625, 1.25, 2.5, 5.0, and $10 \mathrm{~g} / \mathrm{L}$ ) were amended in the PDA medium. The selected concentrations represented $0.0 \%, 25 \%, 50 \%, 100 \%, 200 \%$, and $400 \%$ of the recommended dose $(2.5 \mathrm{~g} / \mathrm{L})$ by the producing company. Agar discs $(0.5 \mathrm{~cm})$ of the three days old colony of T. harzianum JF419706 were inoculated onto Petri plates containing the PDA medium with different doses of the fungicide. Three plates were used for each treatment and were incubated at $27 \pm 1{ }^{\circ} \mathrm{C}$ for five days. The radial growth of the fungus was measured daily.

\subsection{Effectiveness of the FTB in Suppression of Root Rot Disease under Field Conditions}

The ability of the solid-state (fine powder) of the FTB to suppress the root rot disease of cucumber, lettuce, and tomato was evaluated in situ. The efficacy of seed treatment and soil treatment on the root rot disease of cucumber (Cucumi sativus L., cv Beta-alpha), lettuce (Lactuca sativa L., cv Niagra), and tomato (Lycopersicum esculentum L., cv Supemarmind) was carried out under field conditions in sandy loam soil. The previous history of root rot disease in the experimental field was approved $[38,40]$ and the presence of soil-borne pathogens that are involved in causing root rot diseases in the crops were confirmed. Experiments were designed in a completely randomized split-plot regime. For each crop, an area of $100 \mathrm{~m}^{2}$ was used and was divided into plots of $10.5 \mathrm{~m}^{2}$. Each plot contained three rows $(3 \mathrm{~m})$ at an $80 \mathrm{~cm}$ distance for each treatment. The FTB was applied in two 
different treatments: seed treatment and soil treatment. In the seed treatment, the seeds of each vegetable were soaked in a diluted suspension of the FTB for 10 min $(1: 1000, v: v)$ with $2 \%$ of Tween 20 as the stabilizing material. Then, seeds were air-dried and sown directly into the soil. In the control, seeds were soaked in sterilized water with Tween 20 (2\%). In the soil treatment, the FTB was blended with compost to get the final titer of the ingredient organism as $10^{8} \mathrm{CFU} / \mathrm{g}$ compost. The compost containing FTB was applied in a $15-\mathrm{cm}$ furrow in the rows at the rate of $0.45 \mathrm{~kg} / \mathrm{m}^{2}$ one week before sowing. Seeds were sown $20 \mathrm{~cm}$ apart in the hills and normal cultural practices were applied.

When the plants were 90-days old, samples from each plot were taken for pathological, morphological, and physiological analyses on the viability of the biocontrol fungus (T. harzianum JF419706). Disease index and disease severity percentage (DS\%) were assessed as described by Alamri, Hashem, Mostafa, Nafady and Abo-Elyousr [4] using the formula suggested by Kempe and Sequeira [46]. Plant height, fresh and dry weight of shoot and root, and the number of leaves and flowers per plant were estimated. Photosynthetic pigments (chlorophyll a, b, and carotenoids) were estimated in fresh leaf samples a week before the harvest, following the protocol of Lichtenthaler [47] by homogenizing $0.5 \mathrm{~g}$ of fresh leaves in $90 \%(v / v)$ acetone and filtration. The final volume was completed to $50 \mathrm{~mL}$ and the pigment concentrations were calculated from the absorbance of the extract at 663, 648, and $470 \mathrm{~nm}$. The method of Laurentin and Edwards [48] was applied to estimate the total carbohydrates (mg/g dry weight).

The protein amount in the leaves' crude extracts was estimated using Bradford's method [49] by grinding $0.5 \mathrm{~g}$ of dry leaves in $10 \mathrm{~mL}$ of $0.1 \mathrm{M}$ sodium phosphate buffer ( $\mathrm{pH}$ 7.1), and the absorbance of the prepared solution was measured at $595 \mathrm{~nm}$ using a Schimadzu UV-1201 spectrophotometer. Bovine serum albumin (BSA) was used at concentrations of $10,20,30,40,50$, and $60 \mathrm{mg} / \mathrm{mL}$ to conduct the protein standard curve. Proline was determined according to the method described by Bates et al. [50] by measuring the absorbance at $520 \mathrm{~nm}$.

The method described by Malik and Singh [51] was followed to determine the total phenolic contents ( $\mathrm{mg} / \mathrm{g}$ dry weight) of the leaves by measuring the absorbance at $650 \mathrm{~nm}$, and the standard calibration curve was generated at the same absorbance using known concentrations of catechol.

The viability of T. harzianum JF419706 was tested by counting the viable propagules (CFU) in the rhizospheric soil after uprooting the plant roots, at the end of the experiment, by collecting the root-adhering soil particles as described by Qiao et al. [52] with modifications. A serial dilution was made in sterile distilled water and $1 \mathrm{~mL}$ of an appropriate dilution was spread onto Petri plates ( 5 plates per sample) containing PDA medium. The plates were incubated at $27 \pm 1{ }^{\circ} \mathrm{C}$ for 3 days, and the emerged colonies of the target fungus were counted and expressed as CFU/g soil.

\subsection{Statistical Analysis}

The experiments were repeated twice using three replicates for each treatment. The field experiments were conducted for two successive seasons and the shown data are the mean of the two seasons. The SPSS 22.0 software was used to analyze the data (SPSS, 2013). Shapiro-Wilk's W and Levene's tests were applied to test the normality of distribution and homogeneity of variance of the data. Data were analyzed using one-way ANOVA and the significant differences among the means of the treatments were identified using Duncan's multiple tests $(p<0.05)$.

\section{Results}

\subsection{Mass Production and Formulation of Trichoderma harzianum JF419706 (FTB)}

Ten different cheap carriers were chosen for mass production and propagation of T. harzianum JF419706 (Table 1) in vitro. Among the substrates, corn stovers produced the highest propagation of the fungus $\left(1.9 \times 10^{9} \mathrm{CFU} / \mathrm{g}\right)$, followed by wheat straw $\left(1.3 \times 10^{8} \mathrm{CFU} / \mathrm{g}\right)$, rice $\left(8.5 \times 10^{6} \mathrm{CFU} / \mathrm{g}\right)$, and corn stalk $\left(6.5 \times 10^{6} \mathrm{CFU} / \mathrm{g}\right)$ after ten days 
of incubation. The propagules count significantly increased when the time extended to 30 days. However, the ranking of these substances differed and the corn stovers were the highest $\left(2.9 \times 10^{16} \mathrm{CFU} / \mathrm{g}\right)$, followed by rice $\left(2.25 \times 10^{14} \mathrm{CFU} / \mathrm{g}\right)$, corn stalks $\left(4 \times 10^{13} \mathrm{CFU} / \mathrm{g}\right)$, and wheat straw $\left(1.8 \times 10^{13} \mathrm{CFU} / \mathrm{g}\right)$. Results showed that the propagation of the fungus on the corn stovers was higher than other substrates by 100 times.

Table 1. Mass production (CFU/g substrate) of T. harzianum JF419706 on different carriers.

\begin{tabular}{lccc}
\hline \multirow{2}{*}{ Carrier } & & Incubation Time & \\
\cline { 2 - 4 } & $\mathbf{1 0}$ Days & 20 Days & 30 Days \\
\hline Sawdust & $7.50 \times 10^{5 \mathrm{e}}$ & $7.90 \times 10^{8 \mathrm{~d}}$ & $2.65 \times 10^{12 \mathrm{~d}}$ \\
Wheat bran & $4.50 \times 10^{4 \mathrm{f}}$ & $1.10 \times 10^{8 \mathrm{e}}$ & $1.45 \times 10^{11 \mathrm{e}}$ \\
Rice & $8.50 \times 10^{6 \mathrm{~d}}$ & $4.50 \times 10^{11 \mathrm{~b}}$ & $2.25 \times 10^{14 \mathrm{~b}}$ \\
Popcorn & $1.40 \times 10^{5} \mathrm{~g}$ & $1.40 \times 10^{7 \mathrm{~g}}$ & $2.30 \times 10^{9} \mathrm{~g}$ \\
White corn & $1.30 \times 10^{4 \mathrm{~h}}$ & $1.70 \times 10^{8 \mathrm{e}}$ & $2.80 \times 10^{10 \mathrm{f}}$ \\
Red corn & $1.20 \times 10^{4 \mathrm{~h}}$ & $9.50 \times 10^{7 \mathrm{f}}$ & $1.10 \times 10^{10 \mathrm{f}}$ \\
Wheat straw & $1.30 \times 10^{8 \mathrm{~b}}$ & $2.00 \times 10^{11 \mathrm{~b}}$ & $1.80 \times 10^{13 \mathrm{c}}$ \\
Corn stalks & $6.50 \times 10^{6 \mathrm{c}}$ & $2.70 \times 10^{10 \mathrm{c}}$ & $4.00 \times 10^{13 \mathrm{c}}$ \\
Corn stovers & $1.90 \times 10^{9 \mathrm{a}}$ & $1.30 \times 10^{13 \mathrm{a}}$ & $2.90 \times 10^{16 \mathrm{a}}$ \\
Barley & $2.5 \times 10^{6 \mathrm{~d}}$ & $3.80 \times 10^{10 \mathrm{c}}$ & $1.80 \times 10^{12 \mathrm{~d}}$ \\
\hline Values followedby a & & &
\end{tabular}

Values followed by a different letter within the same column are significantly different at $p<0.05$.

\subsection{Shelf-Life of the Formulated Biofungicide (FTB)}

The FTB was stored at room temperature in two different forms: solid state (fine powder and coarse powder) and liquid state (oil emulsion, alginate, and molasses) for up to 8 months. The results in Table 2 showed that both fine powder and oil emulsion succeeded in keeping the viability of FTB in a considerable titer for up to 6 months. The count of CFU decreased gradually after the first month in all stored formulations. However, a dramatic decrease was noticed after the 5th or 6th month on almost all materials. The fine powder was able to keep the count of propagules at $6.37 \times 10^{15} \mathrm{CFU} / \mathrm{g}$ and $9.37 \times 10^{11} \mathrm{CFU} / \mathrm{g}$ after 6 and 8 months, respectively. The viability of the fungus units in oil emulsion was $2.07 \times 10^{15} \mathrm{CFU} / \mathrm{g}$ and $4.2 \times 10^{12} \mathrm{CFU} / \mathrm{g}$ after 6 and 8 months, respectively. The CFU/g in molasses was the lowest among all materials, where after 8 months only $6.5 \times 10^{7} \mathrm{CFU} / \mathrm{g}$ were variable.

Table 2. Shelf-life of the formulated biofungicide from T. harzianum JF419706 (FTB).

\begin{tabular}{cccccc}
\hline \multirow{2}{*}{ Months } & \multicolumn{2}{c}{ Powder (CFU/g) } & \multicolumn{3}{c}{ Liquid (CFU/g) } \\
\cline { 2 - 6 } & Coarse & Fine & Emulsion Oil & Alginate & Molasses \\
\hline 0 & $2.81 \times 10^{16 \mathrm{a}}$ & $5.37 \times 10^{17 \mathrm{a}}$ & $3.00 \times 10^{17 \mathrm{a}}$ & $4.57 \times 10^{16 \mathrm{a}}$ & $4.47 \times 10^{16 \mathrm{a}}$ \\
1 & $2.49 \times 10^{16 \mathrm{a}}$ & $4.47 \times 10^{17 \mathrm{a}}$ & $6.30 \times 10^{17 \mathrm{~b}}$ & $7.10 \times 10^{16 \mathrm{~b}}$ & $4.27 \times 10^{15 \mathrm{~b}}$ \\
2 & $4.12 \times 10^{16 \mathrm{a}}$ & $4.35 \times 10^{17 \mathrm{a}}$ & $4.13 \times 10^{16 \mathrm{~b}}$ & $8.30 \times 10^{16 \mathrm{~b}}$ & $3.75 \times 10^{14 \mathrm{c}}$ \\
3 & $1.76 \times 10^{16 \mathrm{a}}$ & $2.60 \times 10^{17 \mathrm{~b}}$ & $3.45 \times 10^{16 \mathrm{~b}}$ & $4.50 \times 10^{16 \mathrm{c}}$ & $1.77 \times 10^{11 \mathrm{~d}}$ \\
4 & $1.02 \times 10^{16 \mathrm{a}}$ & $1.70 \times 10^{16 \mathrm{c}}$ & $7.60 \times 10^{15 \mathrm{c}}$ & $5.40 \times 10^{15 \mathrm{~d}}$ & $4.80 \times 10^{10 \mathrm{e}}$ \\
5 & $6.43 \times 10^{15 \mathrm{~b}}$ & $3.33 \times 10^{15 \mathrm{~d}}$ & $5.78 \times 10^{16 \mathrm{~d}}$ & $4.62 \times 10^{13 \mathrm{e}}$ & $5.27 \times 10^{9 \mathrm{f}}$ \\
6 & $3.45 \times 10^{13 \mathrm{c}}$ & $6.37 \times 10^{15 \mathrm{~d}}$ & $2.07 \times 10^{15 \mathrm{e}}$ & $4.53 \times 10^{11 \mathrm{f}}$ & $6.67 \times 10^{8} \mathrm{~g}$ \\
7 & $3.30 \times 10^{12 \mathrm{~d}}$ & $2.25 \times 10^{13 \mathrm{e}}$ & $1.50 \times 10^{14 \mathrm{f}}$ & $3.37 \times 10^{11 \mathrm{f}}$ & $1.57 \times 10^{8 \mathrm{~h}}$ \\
8 & $4.63 \times 10^{11 \mathrm{e}}$ & $9.37 \times 10^{11 \mathrm{f}}$ & $4.20 \times 10^{12 \mathrm{~g}}$ & $1.08 \times 10^{10 \mathrm{~g}}$ & $6.50 \times 10^{7 \mathrm{i}}$ \\
\hline
\end{tabular}

Values followed by a different letter within the same column are significantly different at $p<0.05$.

\subsection{Resistance of the Bioagent Fungus to the Chemical Synthetic Fungicide "Rhizolex"}

Rhizolex is a chemical synthetic fungicide commonly used as a seed treatment to protect seeds against a fungal attack with a recommended dose of about $2.5 \mathrm{~g} / \mathrm{L}$. To ensure that our FTB could be applied successfully without affecting the residue of this fungicide, which could be still adherent to the seeds, the toxicity of the fungicide on the viability of T. harzianum JF419706 (FTB) was tested. Figure 1 showed that T. harzianum JF419706 resisted 
the presence of the fungicide up to two-fold of the recommended dose of the chemical fungicide. The lower doses of the fungicide affected the growth of the fungus, and the effect gradually decreased until the end of the experiment (5 days). The recommended dose $(2.5 \mathrm{~g} / \mathrm{L})$ inhibited the radial growth of the fungus by $61.6 \%$ of the control, while this inhibition was lowered to $40.0 \%$ at the end of the incubation period.

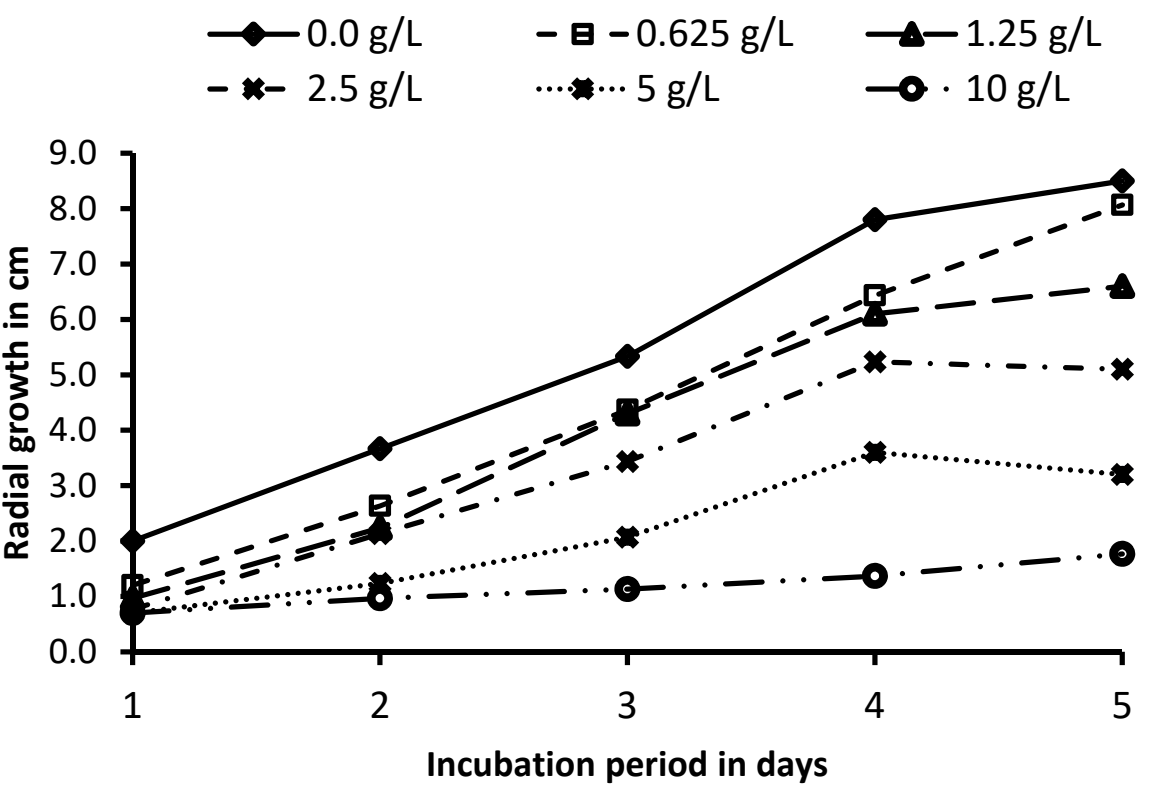

Figure 1. Effect of chemical fungicide Rhizolex on viability and growth of T. harzianum JF419706.

\subsection{The Activity of the Formulated Biofungicide (FTB) in Soil}

The viability of the bioagent ingredient in the FTB in soil was monitored after 90 days. Data in Table 3 showed that the viable CFU of the fungus increased to $5.04 \times 10^{8} \mathrm{CFU} / \mathrm{g}$ and $6.62 \times 10^{8} \mathrm{CFU} / \mathrm{g}$ after 90 days from cultivation compared with $3.27 \times 10^{8}-3.33 \times 10^{8} \mathrm{CFU} / \mathrm{g}$ at the time of infestation ( 0 day) in the rhizospheric soil of the three crops.

Table 3. Viability of T. harzianum JF419706 (FTB) in the rhizospheric soil (counting CFU/g soil) of three vegetable crops.

\begin{tabular}{lcc}
\hline \multirow{2}{*}{ Crop } & \multicolumn{2}{c}{ T. harzianum CFU/g } \\
\cline { 2 - 3 } & Start Date (0 Day) & End Date (90 Days) \\
\hline Cucumber & $3.27 \times 10^{8 \mathrm{a}}$ & $5.04 \times 10^{8 \mathrm{~b}}$ \\
Lettuce & $3.33 \times 10^{8 \mathrm{a}}$ & $5.60 \times 10^{8 \mathrm{~b}}$ \\
Tomato & $3.30 \times 10^{8 \mathrm{a}}$ & $6.62 \times 10^{8 \mathrm{~b}}$ \\
\hline
\end{tabular}

Values followed by a different letter within the same column are significantly different at $p<0.05$.

\subsection{Field Experiments}

Data collected from the field study approved the efficiency of the FTB in the protection of the vegetable crops from root rot diseases and in enhancing their growth rate and productivity. The data in Table 4 clearly showed the effectiveness of the FTB in the suppression of the root rot disease of cucumber plants after 90 days of sowing. Results showed that the application of the FTB as seed treatment was better than drenching in the soil. When the cucumber seeds were treated with the FTB before cultivation, MDR and DS\% were significantly reduced compared with the infected control. Plant height increased to $41.7 \mathrm{~cm}$ compared with $33.0 \mathrm{~cm}$ in the control. The fresh and dry weight of the treated plants was significantly enhanced compared with the control. The number of flowers per plant was used as an indicator of predictable productivity. The number of cucumber flowers was 13.0 flower/plant compared with 8.67 flower/plant in the control. Therefore, the predicted 
productivity could be increase by about $50 \%$ because of the seed treatment with the FTB. There was a consistent result from the morphological and physiological measurements of the cucumber plants that were treated with the FTB. Table 5 demonstrates that the physiological machinery of the treated plant was stimulated and resulted in a significant increase in the photosynthetic pigment formation compared with the control. In general, there was an obvious increase in seed treatment which was higher than soil treatment. Consequently, the total carbohydrates increased in all treatments. Protein content significantly increased compared with the control and the highest quantity was gained in either seed or soil treatment. Proline and phenols in all treatments significantly decreased compared with the control.

Table 4. Effect of FTB on mean disease rating (MDR), disease severity percentage (DS\%), and morphological characteristics of cucumber plants after 90 days of cultivation under field conditions.

\begin{tabular}{|c|c|c|c|c|c|c|c|c|c|c|}
\hline \multirow{2}{*}{$\begin{array}{c}\text { Type of } \\
\text { Application }\end{array}$} & \multirow{2}{*}{ Treatment } & \multirow[t]{2}{*}{ MDR } & \multirow{2}{*}{ DS $\%$} & \multirow{2}{*}{$\begin{array}{l}\text { Plant } \\
\text { Height } \\
\text { (cm) }\end{array}$} & \multicolumn{2}{|c|}{$\begin{array}{l}\text { Shoot Weight } \\
\text { (g/Plant) }\end{array}$} & \multicolumn{2}{|c|}{$\begin{array}{c}\text { Root Weight } \\
\text { (g/Plant) }\end{array}$} & \multirow{2}{*}{$\begin{array}{c}\text { No. of } \\
\text { Leaves/Plant }\end{array}$} & \multirow{2}{*}{$\begin{array}{c}\text { No. of } \\
\text { Flowers/Plant }\end{array}$} \\
\hline & & & & & Fresh & Dry & Fresh & Dry & & \\
\hline \multirow{2}{*}{ Soil treatment } & Control & $2.2 \mathrm{a}$ & $55.0 \mathrm{a}$ & $31.3 c$ & $57.5 \mathrm{~b}$ & $5.6 \mathrm{c}$ & $2.4 \mathrm{c}$ & $0.21 \mathrm{c}$ & $12.0 \mathrm{~b}$ & $8.7 \mathrm{c}$ \\
\hline & FTB & $0.8 \mathrm{~b}$ & $20.0 \mathrm{c}$ & $37.0 \mathrm{~b}$ & $87.5 \mathrm{a}$ & $7.4 \mathrm{~b}$ & $3.4 \mathrm{~b}$ & $0.29 \mathrm{~b}$ & $14.7 \mathrm{a}$ & $12.0 \mathrm{~b}$ \\
\hline \multirow{2}{*}{ Seed treatment } & Control & $2.0 \mathrm{a}$ & $50.0 \mathrm{~b}$ & $33.0 \mathrm{c}$ & $57.4 \mathrm{~b}$ & $5.9 c$ & $2.9 c$ & $0.21 \mathrm{c}$ & $12.7 \mathrm{~b}$ & $8.7 \mathrm{c}$ \\
\hline & FTB & $0.6 \mathrm{~b}$ & $15.0 \mathrm{c}$ & $41.7 \mathrm{a}$ & $84.1 \mathrm{a}$ & $8.1 \mathrm{a}$ & $4.1 \mathrm{a}$ & $0.33 \mathrm{a}$ & $14.3 \mathrm{a}$ & $13.0 \mathrm{a}$ \\
\hline
\end{tabular}

Values followed by a different letter within the same column are significantly different at $p<0.05$.

Table 5. Effect of FTB on the physiological characteristics of 90-days old cucumbers cultivated under field conditions.

\begin{tabular}{|c|c|c|c|c|c|c|c|c|}
\hline \multirow{2}{*}{$\begin{array}{c}\text { Type of } \\
\text { Application }\end{array}$} & \multirow{2}{*}{ Treatment } & \multicolumn{3}{|c|}{ Pigments (mg/g FW) } & \multirow{2}{*}{$\begin{array}{c}\text { Total } \\
\text { Carbohydrates } \\
(\mathrm{mg} / \mathrm{g} \text { FW) }\end{array}$} & \multirow{2}{*}{$\begin{array}{c}\text { Total Proteins } \\
\text { (mg/g DW) }\end{array}$} & \multirow{2}{*}{$\begin{array}{c}\text { Proline } \\
(\mathrm{mg} / \mathrm{g} \text { DW) }\end{array}$} & \multirow{2}{*}{$\begin{array}{c}\text { Total Phenols } \\
\text { (mg/g DW) }\end{array}$} \\
\hline & & Chlorophyll a & Chlorophyll b & Carotenoids & & & & \\
\hline \multirow{2}{*}{ Soil treatment } & Control & $1.28 \mathrm{~b}$ & $0.36 \mathrm{~b}$ & $0.41 \mathrm{~b}$ & $66.35 \mathrm{~d}$ & $5.40 \mathrm{c}$ & $1.08 \mathrm{a}$ & $0.98 \mathrm{a}$ \\
\hline & FTB & $1.30 \mathrm{c}$ & $0.37 \mathrm{~b}$ & $0.44 \mathrm{~b}$ & $85.23 \mathrm{~b}$ & $6.54 \mathrm{~b}$ & $0.76 \mathrm{c}$ & $0.66 \mathrm{c}$ \\
\hline \multirow{2}{*}{ Seed treatment } & Control & $1.34 \mathrm{~b}$ & $0.35 \mathrm{~b}$ & $0.43 \mathrm{~b}$ & $76.15 c$ & $6.62 \mathrm{~b}$ & $1.08 \mathrm{a}$ & $0.96 \mathrm{a}$ \\
\hline & FTB & $1.46 \mathrm{a}$ & $0.43 \mathrm{a}$ & $0.50 \mathrm{a}$ & $88.11 \mathrm{a}$ & $7.20 \mathrm{a}$ & $0.97 \mathrm{~b}$ & $0.77 \mathrm{~b}$ \\
\hline
\end{tabular}

Values followed by a different letter within the same column are significantly different at $p<0.05$.

Table 6 shows that after 90 days, FTB application reduced the root and crown rot severity of lettuce plants to $25 \%$ compared with the untreated plants $(65.0-70 \%)$. The morphological characteristics of the treated plants showed a significant increase over the control. When the FTB was applied as a seed treatment, the fresh weight of lettuce was $624.13 \mathrm{~g} /$ plant compared with $461.5 \mathrm{~g} / \mathrm{plant}$ in the control. This indicates that there was a $35.2 \%$ increase in the productivity of lettuce as the result of FTB application. The increase in leaves number was about $40.0 \%$ from the control. In addition, a real increase in productivity was indicated by a significant increase in the dry weight and the main composition in the leaves including storage materials and minerals, which all enhance the quality and productivity of the vegetable. The significant increase in fresh and dry weight of the roots in all treatments compared with the control confirmed the effectiveness of the FTB in the protection of roots against pathogens' attacks.

Table 6. Effect of FTB on mean disease rating (MDR), disease severity percentage (DS\%), and morphological measurements of lettuce plants after 90 days from cultivation under field conditions.

\begin{tabular}{|c|c|c|c|c|c|c|c|c|c|}
\hline \multirow{2}{*}{$\begin{array}{c}\text { Type of } \\
\text { Application }\end{array}$} & \multirow[t]{2}{*}{ Treatment } & \multirow[t]{2}{*}{ MDR } & \multirow[t]{2}{*}{ DS $\%$} & \multirow{2}{*}{$\begin{array}{l}\text { Plant Height } \\
(\mathrm{cm})\end{array}$} & \multicolumn{2}{|c|}{$\begin{array}{c}\text { Shoot Weight } \\
\text { (g/Plant) }\end{array}$} & \multicolumn{2}{|c|}{$\begin{array}{l}\text { Root Weight } \\
\text { (g/Plant) }\end{array}$} & \multirow{2}{*}{$\begin{array}{c}\text { No. of } \\
\text { Leaves/Plant }\end{array}$} \\
\hline & & & & & Fresh & Dray & Fresh & Dray & \\
\hline \multirow{2}{*}{ Soil treatment } & Control & $2.8 \mathrm{a}$ & $70.0 \mathrm{a}$ & $29.3 d$ & $465.73 \mathrm{c}$ & $17.35 \mathrm{c}$ & $20.89 \mathrm{~d}$ & $2.65 \mathrm{c}$ & $35.33 c$ \\
\hline & FTB & $1.0 \mathrm{c}$ & $25.0 \mathrm{c}$ & $33.3 \mathrm{~b}$ & $522.23 \mathrm{~b}$ & $21.09 \mathrm{~b}$ & $28.93 \mathrm{~b}$ & $3.28 \mathrm{~b}$ & $40.67 \mathrm{~b}$ \\
\hline \multirow{2}{*}{ Seed treatment } & Control & $2.6 \mathrm{~b}$ & $65.0 \mathrm{~b}$ & $32.3 \mathrm{c}$ & $461.50 \mathrm{c}$ & $17.99 \mathrm{c}$ & $23.37 \mathrm{c}$ & $2.74 \mathrm{c}$ & $36.67 c$ \\
\hline & FTB & $1.0 \mathrm{c}$ & $25.0 \mathrm{c}$ & $35.3 \mathrm{a}$ & $624.13 \mathrm{a}$ & $26.66 \mathrm{a}$ & $32.80 \mathrm{a}$ & $3.89 \mathrm{a}$ & $51.33 \mathrm{a}$ \\
\hline
\end{tabular}

Values followed by a different letter within the same column are significantly different at $p<0.05$. 
Table 7 reflects an increase in physiological machinery of the treated plants with the FTB either as a seed or soil treatment. Chlorophyll a and b, carotenoids, carbohydrates, and protein significantly increased compared with the control. Proline and phenols significantly decreased as a result of the application of the FTB compared with the control.

Table 7. Effect of FTB on the physiological characteristics of 90-days old lettuce plants cultivated under field conditions.

\begin{tabular}{|c|c|c|c|c|c|c|c|c|}
\hline \multirow{2}{*}{$\begin{array}{c}\text { Type of } \\
\text { Application }\end{array}$} & \multirow{2}{*}{ Treatment } & \multicolumn{3}{|c|}{ Pigments (mg/g FW) } & \multirow{2}{*}{$\begin{array}{c}\text { Total } \\
\begin{array}{c}\text { Carbohydrates } \\
(\mathrm{mg} / \mathrm{g} \text { FW })\end{array}\end{array}$} & \multirow{2}{*}{$\begin{array}{c}\text { Total Proteins } \\
\text { (mg/g DW) }\end{array}$} & \multirow{2}{*}{$\begin{array}{c}\text { Proline } \\
\text { (mg/g DW) }\end{array}$} & \multirow{2}{*}{$\begin{array}{c}\text { Total Phenols } \\
\text { (mg/g DW) }\end{array}$} \\
\hline & & Chlorophyll a & Chlorophyll b & Carotenoids & & & & \\
\hline \multirow{2}{*}{ Soil treatment } & Control & $1.00 \mathrm{~b}$ & $0.32 \mathrm{~b}$ & $0.38 \mathrm{c}$ & $94.92 \mathrm{~b}$ & $12.13 \mathrm{c}$ & $0.80 \mathrm{a}$ & $1.74 \mathrm{~b}$ \\
\hline & FTB & $1.31 \mathrm{a}$ & $0.38 \mathrm{a}$ & $0.46 \mathrm{a}$ & $120.77 \mathrm{a}$ & $14.57 \mathrm{~b}$ & $0.57 \mathrm{c}$ & $1.53 \mathrm{c}$ \\
\hline \multirow{2}{*}{ Seed treatment } & Control & $1.11 \mathrm{~b}$ & $0.27 \mathrm{c}$ & $0.41 \mathrm{~b}$ & $82.85 \mathrm{c}$ & $14.54 \mathrm{~b}$ & $0.66 \mathrm{~b}$ & $2.06 \mathrm{a}$ \\
\hline & FTB & $1.23 \mathrm{a}$ & $0.38 \mathrm{a}$ & $0.48 \mathrm{a}$ & $93.88 \mathrm{~b}$ & $20.74 \mathrm{a}$ & $0.64 \mathrm{~b}$ & $1.61 \mathrm{c}$ \\
\hline
\end{tabular}

Values followed by a different letter within the same column are significantly different at $p<0.05$.

Table 8 shows that tomato plants were more sensitive to the root rot disease infection than the other two vegetables (cucumber and lettuce) where the MDR reached 3 and DS\% was $75 \%$ in soil treatment. The morphological parameters were altered significantly because of infection. However, the application of the FTB significantly reduced the disease severity on tomato plants to $30.0 \%$ in both types of treatments. Plant height, number of leaves, shoots, and dry weight achieved a significant increase compared with the control. Seed treatment showed better results than soil treatment in almost all cases. An interesting observation was that the number of flowers was 17.67 flower/plant when the FTB was applied as a seed treatment compared with 13.67 flower/plant in the control. The predicted yield could be increased by $29.0 \%$ from the control. Table 9 indicates a good stimulation in the physiology of tomato plants after treatment with the FTB. The photosynthetic pigments significantly increased compared with the control, especially in the case of seed treatment. Carbohydrates and protein content were significantly higher than those in control; however, proline and phenols were reduced.

Table 8. Effect of FTB on mean disease rating (MDR), disease severity percentage (DS\%), and morphological measurements of tomato plants after 90 days from cultivation under field conditions.

\begin{tabular}{|c|c|c|c|c|c|c|c|c|c|c|}
\hline \multirow{2}{*}{$\begin{array}{c}\text { Type of } \\
\text { Application }\end{array}$} & \multirow{2}{*}{ Treatment } & \multirow{2}{*}{ MDR } & \multirow{2}{*}{ DS\% } & \multirow{2}{*}{$\begin{array}{l}\text { Plant } \\
\text { Height } \\
\text { (cm) }\end{array}$} & \multicolumn{2}{|c|}{$\begin{array}{c}\text { Shoot Weight } \\
\text { (g/Plant) }\end{array}$} & \multicolumn{2}{|c|}{$\begin{array}{c}\text { Root Weight } \\
\text { (g/Plant) }\end{array}$} & \multirow{2}{*}{$\begin{array}{c}\text { No. of } \\
\text { Leaves/Plant }\end{array}$} & \multirow{2}{*}{$\begin{array}{c}\text { No. of } \\
\text { Flowers/Plant }\end{array}$} \\
\hline & & & & & Fresh & Dry & Fresh & Dry & & \\
\hline \multirow{2}{*}{ Soil treatment } & Control & $3.0 \mathrm{a}$ & $70.0 \mathrm{a}$ & $47.7 \mathrm{c}$ & $63.8 \mathrm{~d}$ & $5.83 \mathrm{~d}$ & $3.45 \mathrm{c}$ & $0.46 \mathrm{c}$ & $14.0 \mathrm{c}$ & $11.0 \mathrm{c}$ \\
\hline & FTB & $1.2 \mathrm{c}$ & $30.0 \mathrm{c}$ & $52.3 \mathrm{~b}$ & $69.7 c$ & $6.89 \mathrm{~b}$ & $3.81 \mathrm{~b}$ & $0.51 \mathrm{~b}$ & $15.0 \mathrm{~b}$ & $13.7 \mathrm{~b}$ \\
\hline \multirow{2}{*}{ Seed treatment } & Control & $2.8 \mathrm{~b}$ & $65.0 \mathrm{~b}$ & $51.7 \mathrm{~b}$ & $75.3 \mathrm{~b}$ & $6.11 \mathrm{c}$ & $3.53 \mathrm{~b}$ & $0.47 \mathrm{c}$ & $15.3 \mathrm{~b}$ & $13.7 \mathrm{~b}$ \\
\hline & FTB & $1.2 \mathrm{c}$ & $30.0 \mathrm{c}$ & $59.3 \mathrm{a}$ & $94.6 \mathrm{a}$ & $8.90 \mathrm{a}$ & $5.27 \mathrm{a}$ & $0.72 \mathrm{a}$ & $16.3 \mathrm{a}$ & $17.8 \mathrm{a}$ \\
\hline
\end{tabular}

Values followed by a different letter within the same column are significantly different at $p<0.05$.

Table 9. Effect of FTB on the physiological characteristics of 90-days old tomato plants cultivated under field conditions.

\begin{tabular}{|c|c|c|c|c|c|c|c|c|}
\hline \multirow{2}{*}{$\begin{array}{c}\text { Type of } \\
\text { Application }\end{array}$} & \multirow{2}{*}{ Treatment } & \multicolumn{3}{|c|}{ Pigments (mg/g FW) } & \multirow{2}{*}{$\begin{array}{c}\text { Total } \\
\text { Carbohydrates } \\
(\mathrm{mg} / \mathrm{g} \text { FW })\end{array}$} & \multirow{2}{*}{$\begin{array}{l}\text { Total Proteins } \\
\text { (mg/g DW) }\end{array}$} & \multirow{2}{*}{$\begin{array}{c}\text { Proline } \\
\text { (mg/g DW) }\end{array}$} & \multirow{2}{*}{$\begin{array}{c}\text { Total Phenols } \\
\text { (mg/g DW) }\end{array}$} \\
\hline & & Chlorophyll a & Chlorophyll b & Carotenoids & & & & \\
\hline \multirow{2}{*}{ Soil treatment } & Control & $0.55 \mathrm{~d}$ & $0.21 \mathrm{~d}$ & $0.18 \mathrm{~d}$ & $57.76 \mathrm{~b}$ & $3.73 \mathrm{c}$ & 2.03 & $0.98 \mathrm{~b}$ \\
\hline & FTB & $1.33 \mathrm{~b}$ & $0.33 \mathrm{c}$ & $0.42 \mathrm{~b}$ & $63.97 \mathrm{a}$ & $3.88 \mathrm{c}$ & 1.14 & $0.82 \mathrm{~d}$ \\
\hline \multirow{2}{*}{ Seed treatment } & Control & $0.69 c$ & $0.40 \mathrm{~b}$ & $0.23 c$ & $51.84 \mathrm{c}$ & $4.25 \mathrm{~b}$ & 1.88 & $1.24 \mathrm{a}$ \\
\hline & FTB & $1.50 \mathrm{a}$ & $0.49 \mathrm{a}$ & $0.56 \mathrm{a}$ & $57.87 \mathrm{~b}$ & $5.15 \mathrm{a}$ & 1.23 & $0.92 \mathrm{c}$ \\
\hline
\end{tabular}

Values followed by a different letter within the same column are significantly different at $p<0.05$.

\section{Discussion}

Our results showed the highest mass productivity of T. harzianum on corn stovers with $2 \%$ date molasses as an economic and effective carrier. It could be assumed that cellulose and other macro and micronutrients contained in the corn stovers in addition to the simple sugars in molasses stimulated the propagation and sporulation of the fungus. The fine powder of the carrier kept the viability of the bioagent fungus up to 8 months at room temperature as an appropriate shelf-life time of the FTB. Along with our finding, Kumar and 
Palakshappa [53] reported a significant increase in the population of Trichoderma harzianum on the molasses yeast medium. Gangwar et al. [54] reported many suitable media for the mass production of T. harzianum; among them, sand maize and sorghum grain were mentioned as useful media for mass multiplication of this fungus. In their experiment to find the appropriate cheap substrate to grow Trichoderma lixii TvR1a, Sachdev, Singh and Singh [34] mentioned that sugarcane bagasse supported the maximum growth of the fungus $\left(2.0 \times 10^{8}\right.$ spores $\left./ \mathrm{g}\right)$. Good propagation of the fungus on the fine powder of the carrier could be due to the larger exposed surface area for the fungal spores to grow and propagate. The addition of molasses appeared as an important material to enhance the propagation of the fungus and to keep the osmotic medium of the formulation $[7,53]$. Because the formulation of biocontrol agents is the most important step in the overall production process, the formulation should ensure the protection of the active ingredients (spores, conidia, mycelial germlings of antagonistic fungi) from extreme $\mathrm{pHs}$, low humidity, chemicals, and UV radiation [55]. The formulated FTB should exhibit antagonistic activity against the target pathogens without being affected by adverse environmental factors. In accordance with our results, different types of formulations of Trichoderma such as invert emulsion, cane molasses amendment, seed coating, pregelatinized starch flour granules, wettable powder, alginate pellets, and gluten matrix were applied $[7,22,26,34,55,56]$. Lewis et al. (1990) mentioned that either conidia of T. hamatum and T. virens or their formulation reduced the disease severity by more than $80 \%$ and suppressed the growth of the pathogen by $75 \%$ under greenhouse conditions. Bae and Knudsen [57] and McLean et al. [58] have demonstrated that biocontrol activity of the formulated Trichoderma spp. in the soil was dependent on the substrate used in the formulation. The availability of a cost-effective substrate that enhances the stabilization and propagation of the antagonist is a crucial factor when selecting the commercial development of a formulated biofungicide $[21,34,59]$.

The abundance of microbial propagules, cost-effective production, surviving, shelflife, tolerance to environmental conditions, and efficiency in field trials are the main requirements of the ideal biofungicide $[7,60]$. Our results confirm that the present FTB likely fits the above-mentioned characteristics. In addition, the bioagent fungus resisted the presence of the fungicide up to two-fold of the recommended dose of the chemical fungicide. This finding adds an excellent property for the new formulation to ensure that it can resist the presence of the chemical fungicide especially in low doses, and gives the validity of the application of the FTB even in the presence of other chemical fungicides [61]. In rhizospheric soil, the FTB showed good survival and propagation. This finding supports the assumption that the addition of the FTB could enhance the suppressive effect of the treated soil and could make such soil become self-suppressive after several additions of the FTB during successive seasons [62,63].

The results obtained from the field experiments proved that the three vegetable crops were susceptible to infection with the root rot diseases; however, in various degrees, the tomato was the most sensitive crop where the DS\% on it was $75 \%$ after 90 days from cultivation. The FTB protected the plants against root diseases and enhanced their morphology and physiology. Seed treatment with the FTB was more effective than soil treatment. Our results were supported by the findings of many other researchers, who reported the efficacy of Trichoderma as a bioagent against many soil-borne diseases in the reduction of the disease severity of root rot, and its ability to increase the productivity of the treated crops under greenhouse or field conditions [26,64-66]. The growth parameters plant height, shoot, and root biomass were greatly enhanced because of the application of the FTB. Physiological aspects of the treated plants were significantly different compared with the control. There was an increase in photosynthetic pigments of chlorophyll $a$ and $b$ and carotenoids. Proline and phenols significantly increased in the control; however, their levels decreased significantly because of FTB application. Previous findings confirmed that the interaction of Trichoderma strains with the plants promoted disease resistance, and enhanced plant growth, nutrient availability, and crop yield [4,55]. In addition to their suppressive effect on pathogens, some Trichoderma spp. could colonize the root 
surface, and induce the exchange of compounds that can cause substantial changes in plant metabolism [67-69]. The induction of plant resistance mechanisms by Trichoderma spp. was proven to induce the production of defense-related metabolites in the plant. This includes enzymes that are involved in the biosynthesis of phytoalexins to alleviate oxidative stress, and the synthesis of pathogenesis-related proteins (PR-proteins) [70-72]. The content of phenolic compounds was positively proportioned to the degree of plant resistance against the pathogens [73]. The increase in vegetative growth and crop yield could be because T. harzianum JF419706 has a prolonged growth-promoting effect on the three crops until the end of the season [74]. The findings of other researchers who carried out their experiments in greenhouses reported a considerable increase in yield when plant seeds were pre-treated with a Trichoderma spore suspension [75,76]. When Trichoderma harzianum ITEM 3636 was formulated in commercial biological control products and was applied as a seed treatment, the disease severity of root rot of peanuts caused by Fusarium solani was significantly decreased [77].

\section{Conclusions}

Despite the presence of many commercial biocontrol formulations based on Trichoderma spp., new strong bioagents that can be propagated on a very cheap substrate, suppress the diseases for a long time, and resist the chemical fungicides' residue are very important to ensure sustainable production of the biofungicides. Our newly formulated bioagent almost appeared as an ideal bioagent that fulfilled the required properties to make it an effective biofungicide. The study proved the new strain T. harzianum JF419706 is an effective ingredient of the FTB that could safely be applied under field conditions to control the root rot diseases and soil-borne pathogens infecting vegetable crops. The high biomass productivity of the bioagent, prolonged shelf-life time and resistance to fungicides, encourage the application of the formulated FTB on a larger scale. Enhancement of growth and productivity of the crops prove the efficiency of the FTB as a biofertilizer as well. The study recommends the production of the FTB commercially as cost-effective with applications in both classical and green farming.

Author Contributions: Conceptualization, M.H., Y.S.M. and S.A.; methodology, Y.S.M. and M.H.; formal analysis, E.M.E. and A.M.A.; data curation, M.H., Y.S.M. and E.M.E.; writing-original draft preparation, M.H., S.A. and A.M.A.; writing-review and editing, M.H. and S.A.; project administration, S.A.; funding acquisition, Y.S.M. All authors have read and agreed to the published version of the manuscript.

Funding: This research was funded by King Khalid University and the Ministry of Education in KSA through the project number IFP-KKU-2020/2.

Acknowledgments: The authors extend their appreciation to the Scientific Research Deanship at King Khalid University and the Ministry of Education in KSA for funding this research work through the project number IFP-KKU-2020/2.

Conflicts of Interest: The authors declare no conflict of interest.

\section{References}

1. Khabbaz, S.E.; Abbasi, P.A. Isolation, characterization, and formulation of antagonistic bacteria for the management of seedlings damping-off and root rot disease of cucumber. Can. J. Microbiol. 2014, 60, 25-33. [CrossRef]

2. Heydari, A.; Pessarakli, M. A review on biological control of fungal plant pathogens using microbial antagonists. J. Biol. Sci. 2010, 10, 273-290. [CrossRef]

3. Mitsuboshi, M.; Kioka, Y.; Noguchi, K.; Asakawa, S. Evaluation of suppressiveness of soils exhibiting soil-borne disease suppression after long-term application of organic amendments by the co-cultivation method of pathogenic Fusarium oxysporum and indigenous soil microorganisms. Microbes Environ. 2018, 33, 58-65. [CrossRef]

4. Alamri, S.A.M.; Hashem, M.; Mostafa, Y.S.; Nafady, N.A.; Abo-Elyousr, K.A.M. Biological control of root rot in lettuce caused by Exserohilum rostratum and Fusarium oxysporum via induction of the defense mechanism. Biol. Control 2019, 128, 76-84. [CrossRef]

5. Crowder, D.W.; Harwood, J.D. Promoting Biological Control in a Rapidly Changing World; Elsevier: Amsterdam, The Netherlands, 2014. 
6. Meisner, A.; De Boer, W. Strategies to maintain natural biocontrol of soil-borne crop diseases during severe drought and rainfall events. Front. Microbiol. 2018, 9, 2279. [CrossRef] [PubMed]

7. Locatelli, G.O.; dos Santos, G.F.; Botelho, P.S.; Finkler, C.L.L.; Bueno, L.A. Development of Trichoderma sp. formulations in encapsulated granules (CG) and evaluation of conidia shelf-life. Biol. Control 2018, 117, 21-29. [CrossRef]

8. Babau, A.; Micle, V.; Damian, G.; Sur, I. Preliminary investigations regarding the potential of Robinia pseudoacacia l.(leguminosae) in the phytoremediation of sterile dumps. J. Environ. Protect. Ecol. 2020, 21, 46-55.

9. Damian, G.E.; Micle, V.; Sur, I.M.; Băbău, A.M.C. From environmental ethics to sustainable decision-making: Assessment of potential ecological risk in soils around abandoned mining areas-case study "Larga de Sus mine"(Romania). J. Agric. Environ. Ethics 2019, 32, 27-49. [CrossRef]

10. Canciu, A.; Tertis, M.; Hosu, O.; Cernat, A.; Cristea, C.; Graur, F. Modern analytical techniques for detection of bacteria in surface and wastewaters. Sustainability 2021, 13, 7229. [CrossRef]

11. Naher, L.; Yusuf, U.K.; Ismail, A.; Hossain, K. Trichoderma spp.: A biocontrol agent for sustainable management of plant diseases. Pak. J. Bot. 2014, 46, 1489-1493.

12. Papoutsis, K.; Mathioudakis, M.M.; Hasperué, J.H.; Ziogas, V. Non-chemical treatments for preventing the postharvest fungal rotting of citrus caused by Penicillium digitatum (green mold) and Penicillium italicum (blue mold). Trends Food Sci. Technol. 2019, 86, 479-491. [CrossRef]

13. Chellemi, D.O. Nonchemical management of soilborne pests in fresh market vegetable production systems. Phytopathology 2002, 92, 1367-1372. [CrossRef]

14. Kobori, N.N.; Mascarin, G.M.; Jackson, M.A.; Schisler, D.A. Liquid culture production of microsclerotia and submerged conidia by Trichoderma harzianum active against damping-off disease caused by Rhizoctonia solani. Fungal Biol. 2015, 119, 179-190. [CrossRef]

15. Glare, T.; Caradus, J.; Gelernter, W.; Jackson, T.; Keyhani, N.; Köhl, J.; Marrone, P.; Morin, L.; Stewart, A. Have biopesticides come of age? Trends Biotechnol. 2012, 30, 250-258. [CrossRef]

16. van Lenteren, J.C.; Bolckmans, K.; Köhl, J.; Ravensberg, W.J.; Urbaneja, A. Biological control using invertebrates and microorganisms: Plenty of new opportunities. BioControl 2018, 63, 39-59. [CrossRef]

17. Köhl, J.; Kolnaar, R.; Ravensberg, W.J. Mode of action of microbial biological control agents against plant diseases: Relevance beyond efficacy. Front. Plant Sci. 2019, 10, 845. [CrossRef] [PubMed]

18. Jayaraj, J.; Radhakrishnan, N.V.; Velazhahan, R. Development of formulations of Trichoderma harzianum strain M1 for control of damping-off of tomato caused by Pythium aphanidermatum. Arch. Phytopathol. Plant Protect. 2006, 39, 1-8. [CrossRef]

19. Legrand, F.; Picot, A.; Cobo-Díaz, J.F.; Chen, W.; Le Floch, G. Challenges facing the biological control strategies for the management of Fusarium Head Blight of cereals caused by F. graminearum. Biol. Control 2017, 113, 26-38. [CrossRef]

20. Singh, P.C.; Nautiyal, C.S. A novel method to prepare concentrated conidial biomass formulation of Trichoderma harzianum for seed application. J. Appl. Microbiol. 2012, 113, 1442-1450. [CrossRef]

21. Spadaro, D.; Gullino, M.L. Improving the efficacy of biocontrol agents against soilborne pathogens. Crop. Protect. 2005, 24, 601-613. [CrossRef]

22. Mukherjee, P.K.; Mehetre, S.T.; Sherkhane, P.D.; Muthukathan, G.; Ghosh, A.; Kotasthane, A.S.; Khare, N.; Rathod, P.; Sharma, K.K.; Nath, R. A novel seed-dressing formulation based on an improved mutant strain of Trichoderma virens, and its field evaluation. Front. Microbiol. 2019, 10, 1910. [CrossRef] [PubMed]

23. Leggett, M.; Leland, J.; Kellar, K.; Epp, B. Formulation of microbial biocontrol agents-an industrial perspective. Can. J. Plant Pathol. 2011, 33, 101-107. [CrossRef]

24. Emmert, E.A.B.; Handelsman, J. Biocontrol of plant disease: A (Gram-) positive perspective. FEMS Microbiol. Lett. 1999, 171, 1-9. [CrossRef]

25. Koch, E.; Becker, J.O.; Berg, G.; Hauschild, R.; Jehle, J.; Köhl, J.; Smalla, K. Biocontrol of plant diseases is not an unsafe technology! J. Plant Dis. Protect. 2018, 125, 121-125. [CrossRef]

26. Herrera, W.; Valbuena, O.; Pavone-Maniscalco, D. Formulation of Trichoderma asperellum TV190 for biological control of Rhizoctonia solani on corn seedlings. Egypt. J. Biol. Pest Control 2020, 30, 1-8. [CrossRef]

27. Chen, W.-C.; Chiou, T.-Y.; Delgado, A.L.; Liao, C.-S. The control of rice blast disease by the novel biofungicide formulations. Sustainability 2019, 11, 3449. [CrossRef]

28. de la Cruz Quiroz, R.; Maldonado, J.J.C.; Alanis, M.d.J.R.; Torres, J.A.; Saldívar, R.P. Fungi-based biopesticides: Shelf-life preservation technologies used in commercial products. J. Pest Sci. 2019, 92, 1003-1015. [CrossRef]

29. Kumar, J.; Ramlal, A.; Mallick, D.; Mishra, V. An Overview of Some Biopesticides and Their Importance in Plant Protection for Commercial Acceptance. Plants 2021, 10, 1185. [CrossRef]

30. Kakvan, N.; Heydari, A.; Zamanizadeh, H.R.; Rezaee, S.; Naraghi, L. Development of new bioformulations using Trichoderma and Talaromyces fungal antagonists for biological control of sugar beet damping-off disease. Crop Protect. 2013, 53, 80-84. [CrossRef]

31. Javanshir Javid, K.; Mahdian, S.; Behboudi, K.; Alizadeh, H. Biological control of Fusarium oxysporum f. sp. radicis-cucumerinum by some Trichoderma harzianum isolates. Arch. Phytopathol. Plant Protect. 2016, 49, 471-484. [CrossRef]

32. Khan, S.; Guo, L.; Maimaiti, Y.; Mijit, M.; Qiu, D. Entomopathogenic fungi as microbial biocontrol agent. Mol. Plant Breed. 2012, 3 , 63-79. [CrossRef]

33. Moosavi, M.R.; Zare, R. (Eds.) Factors Affecting Commercial Success of Biocontrol Agents of Phytonematodes. In Biocontrol Agents of Phytonematodes; CABI: Wallingford, UK, 2015; pp. 423-445. 
34. Sachdev, S.; Singh, A.; Singh, R.P. Optimization of culture conditions for mass production and bio-formulation of Trichoderma using response surface methodology. 3 Biotech 2018, 8, 1-8. [CrossRef]

35. Ardakani, S.; Heydari, A.; Khorasani, N.; Arjmandi, R.; Ehteshami, M. Preparation of new biofungicides using antagonistic bacteria and mineral compounds for controlling cotton seedling damping-off disease. J. Plant Protect. Res. 2009, 49, 49-56. [CrossRef]

36. Heydari, A. Biological control of turfgrass fungal diseases. In Handbook of Turfgrass Management and Physiology; CRC Press: Boca Raton, FL, USA, 2007; pp. 228-240.

37. Galindo, E.; Serrano-Carreón, L.; Gutiérrez, C.R.; Allende, R.; Balderas, K.; Patiño, M.; Trejo, M.; Wong, M.A.; Rayo, E.; Isauro, D. The challenges of introducing a new biofungicide to the market: A case study. Electron. J. Biotechnol. 2013, 16, 5. [CrossRef]

38. Alamri, S.; Hashem, M.; Mostafa, Y.S. In vitro and in vivo biocontrol of soil-borne phytopathogenic fungi by certain bioagents and their possible mode of action. Biocontrol Sci. 2012, 17, 155-167. [CrossRef]

39. Alamri, S.; Mostafa, Y.S.; Hashem, M.; Alrumman, S. Enhancing the biocontrol efficiency of Trichoderma harzianum JF419706 through cell wall degrading enzyme production. Int. J. Agric. Biol. 2016, 18, 765-772. [CrossRef]

40. Alamri, S.A.; Hashem, M.; Hafez, E.E.; Moustafa, Y.S.; Alrumman, S.A.; Taha, T.H. The efficiency of two new formulated biofungicides in the control of damping-off and root rot of cucumber and improving the plant defence system. Arch. Phytopathol. Plant Protect. 2012, 45, 1673-1691. [CrossRef]

41. Perazzolli, M.; Roatti, B.; Bozza, E.; Pertot, I. Trichoderma harzianum T39 induces resistance against downy mildew by priming for defense without costs for grapevine. Biol. Control 2011, 58, 74-82. [CrossRef]

42. Vitale, A.; Cirvilleri, G.; Castello, I.; Aiello, D.; Polizzi, G. Evaluation of Trichoderma harzianum strain T22 as biological control agent of Calonectria pauciramosa. BioControl 2012, 57, 687-696. [CrossRef]

43. Poveda, J. Trichoderma as biocontrol agent against pests: New uses for a mycoparasite. Biol. Control 2021, 159, 104634. [CrossRef]

44. Ganuza, M.; Pastor, N.; Erazo, J.; Andrés, J.; Reynoso, M.M.; Rovera, M.; Torres, A.M. Efficacy of the biocontrol agent Trichoderma harzianum ITEM 3636 against peanut smut, an emergent disease caused by Thecaphora frezii. Eur. J. Plant Pathol. 2018, 151, 257-262. [CrossRef]

45. Ausubel, F.M.; Brent, R.; Kingston, R.E.; Moore, D.D.; Seidman, J.G.; Smith, J.A.; Struhl, K. Short Protocols in Molecular Biology: A Compendium of Methods from Current Protocols in Molecular Biology; Wiley: New York, NY, USA, 1995.

46. Kempe, J.; Sequeira, L. Biological control of bacterial wilt of potatoes: Attempts to induce resistance by treating tubers with bacteria. Plant Dis. 1983, 67, 499-503. [CrossRef]

47. Lichtenthaler, H.K. Chlorophylls and carotenoids: Pigments of photosynthetic biomembranes. Methods Enzymol. 1987, 148, 350-382.

48. Laurentin, A.; Edwards, C.A. A microtiter modification of the anthrone-sulfuric acid colorimetric assay for glucose-based carbohydrates. Anal. Biochem. 2003, 315, 143-145. [CrossRef]

49. Bradford, M.M. A rapid and sensitive method for the quantitation of microgram quantities of protein utilizing the principle of protein-dye binding. Anal. Biochem. 1976, 72, 248-254. [CrossRef]

50. Bates, L.S.; Waldren, R.P.; Teare, I.D. Rapid determination of free proline for water-stress studies. Plant Soil 1973, 39, 205-207. [CrossRef]

51. Malik, C.P.; Singh, M.B. Plant Enzymology and Histo-Enzymology; Kalyani Publishers: New Delhi, India, 1980.

52. Qiao, Q.; Zhang, J.; Ma, C.; Wang, F.; Chen, Y.; Zhang, C.; Zhang, H.; Zhang, J. Characterization and variation of the rhizosphere fungal community structure of cultivated tetraploid cotton. PLoS ONE 2019, 14, e0207903. [CrossRef] [PubMed]

53. Kumar, T.P.; Palakshappa, M.G. Evaluation of suitable substrates for on farm production of antagonist Trichoderma harzianum. Karnataka J. Agric. Sci. 2009, 22, 115-117.

54. Gangwar, O.P.; Sharma, P.; Singh, U.D. Growth and survival of Trichoderma harzianum and Pseudomonas fluorescens on different substrates and their temporal and spatial population dynamics in irrigated rice ecosystem. Indian Phytopathol. 2013, 66, 252-257.

55. Verma, M.; Brar, S.K.; Tyagi, R.D.; Surampalli, R.Y.; Valero, J.R. Antagonistic fungi, Trichoderma spp.: Panoply of biological control. Biochem. Eng. J. 2007, 37, 1-20. [CrossRef]

56. Ramanujam, B.; Prasad, R.D.; Sriram, S.; Rangeswaran, R. Mass production, formulation, quality control and delivery of Trichoderma for plant disease management. J. Plant Protect. Sci. 2010, 2, 1-8.

57. Bae, Y.S.; Knudsen, G.R. Soil microbial biomass influence on growth and biocontrol efficacy of Trichoderma harzianum. Biol. Control 2005, 32, 236-242. [CrossRef]

58. McLean, K.L.; Swaminathan, J.; Frampton, C.M.; Hunt, J.S.; Ridgway, H.J.; Stewart, A. Effect of formulation on the rhizosphere competence and biocontrol ability of Trichoderma atroviride C52. Plant Pathol. 2005, 54, 212-218. [CrossRef]

59. Albajes, R.; Gullino, M.L.; van Lenteren, J.C.; Elad, Y. Integrated Pest and Disease Management in Greenhouse Crops; Springer Science \& Business Media: Berlin/Heidelberg, Germany, 2000; Volume 14.

60. Harman, G.E.; Kubicek, C.P. Trichoderma and Gliocladium, Volume 2: Enzymes, Biological Control and Commercial Applications; CRC Press: Boca Raton, FL, USA, 1998.

61. Kapteyn, J.C.; Pillmoor, J.B.; De Waard, M.A. Biochemical mechanisms involved in selective fungitoxicity of two sterol $14 \alpha$-demethylation inhibitors, prochloraz and quinconazole: Accumulation and metabolism studies. Pestic. Sci. 1992, 36, 85-93. [CrossRef] 
62. Chandrashekara, C.; Bhatt, J.C.; Kumar, R.; Chandrashekara, K.N. Supressive soils in plant disease management. In Eco-Friendly Innovative Approaches in Plant Disease Management; Singh, A., Ed.; International Book Distributors: New Delhi, India, 2012; pp. 241-256.

63. Cha, J.-Y.; Han, S.; Hong, H.-J.; Cho, H.; Kim, D.; Kwon, Y.; Kwon, S.-K.; Crüsemann, M.; Lee, Y.B.; Kim, J.F. Microbial and biochemical basis of a Fusarium wilt-suppressive soil. ISME J. 2016, 10, 119-129. [CrossRef]

64. Srobarova, A.; Eged, S. Trichoderma and sulphoethyl glucan reduce maize root rot infestation and fusaric acid content. Plant Soil Environ. 2005, 51, 322. [CrossRef]

65. Cole, J.S.; Zvenyika, Z. Integrated control of Rhizoctonia solani and Fusarium solani in tobacco transplants with Trichoderma hurziunum and triadimenol. Plant Pathol. 1988, 37, 271-277. [CrossRef]

66. Sivan, A.; Ucko, O.; Chet, I. Biological control of Fusarium crown rot of tomato by Trichoderma harzianum under field conditions. Plant Dis. 1987, 71, 587-592. [CrossRef]

67. Harman, G.E.; Howell, C.R.; Viterbo, A.; Chet, I.; Lorito, M. Trichoderma species-Opportunistic, avirulent plant symbionts. Nat. Rev. Microbiol. 2004, 2, 43. [CrossRef]

68. Yedidia, I.; Benhamou, N.; Kapulnik, Y.; Chet, I. Induction and accumulation of PR proteins activityduring early stages of root colonizationby the mycoparasite Trichoderma harzianum strain T-203. Plant Physiol. Biochem. 2000, 38, 863-873. [CrossRef]

69. Hermosa, R.; Viterbo, A.; Chet, I.; Monte, E. Plant-beneficial effects of Trichoderma and of its genes. Microbiology 2012, 158, 17-25. [CrossRef]

70. Yedidia, I.; Shoresh, M.; Kerem, Z.; Benhamou, N.; Kapulnik, Y.; Chet, I. Concomitant induction of systemic resistance to Pseudomonas syringae pv. lachrymans in cucumber by Trichoderma asperellum (T-203) and accumulation of phytoalexins. Appl. Environ. Microbiol. 2003, 69, 7343-7353. [CrossRef]

71. Cai, F.; Yu, G.; Wang, P.; Wei, Z.; Fu, L.; Shen, Q.; Chen, W. Harzianolide, a novel plant growth regulator and systemic resistance elicitor from Trichoderma harzianum. Plant Physiol. Biochem. 2013, 73, 106-113. [CrossRef] [PubMed]

72. Nawrocka, J.; Małolepsza, U.; Szymczak, K.; Szczech, M. Involvement of metabolic components, volatile compounds, PR proteins, and mechanical strengthening in multilayer protection of cucumber plants against Rhizoctonia solani activated by Trichoderma atroviride TRS25. Protoplasma 2018, 255, 359-373. [CrossRef] [PubMed]

73. Abo-Elyousr, K.A.M.; Hashem, M.; Ali, E.H. Integrated control of cotton root rot disease by mixing fungal biocontrol agents and resistance inducers. Crop Protect. 2009, 28, 295-301. [CrossRef]

74. Lynch, J.M.; Wilson, K.L.; Ousley, M.A.; Whipps, J.M. Response of lettuce to Trichoderma treatment. Lett. Appl. Microbiol. 1991, 12, 59-61. [CrossRef]

75. Chet, I.; Inbar, J. Biological control of fungal pathogens. Appl. Biochem. Biotechnol. 1994, 48, 37-43. [CrossRef]

76. Guler, N.S.; Pehlivan, N.; Karaoglu, S.A.; Guzel, S.; Bozdeveci, A. Trichoderma atroviride ID20G inoculation ameliorates drought stress-induced damages by improving antioxidant defence in maize seedlings. Acta Physiol. Plant 2016, 38, 132. [CrossRef]

77. Rojo, F.G.; Reynoso, M.M.; Ferez, M.; Chulze, S.N.; Torres, A.M. Biological control by Trichoderma species of Fusarium solani causing peanut brown root rot under field conditions. Crop Protect. 2007, 26, 549-555. [CrossRef] 